\title{
A quem pertencem as luvas? Reflexões sobre o relato Que cavalos são aqueles que fazem sombra no mar?, de António Lobo Antunes
}

\author{
Cid Ottoni Bylaardt \\ Universidade Federal do Ceará
}

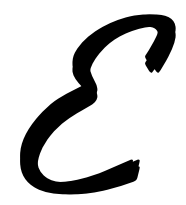

m seu ensaio "A literatura e o direito à morte", Maurice Blanchot faz algumas considerações sobre a atitude do escritor em relação ao seu texto. Para ele, o engano e a mistificação presidem o texto literário, e constituem a honestidade do escritor, por mais que ele esteja cheio de verdade e de esperança. A cabeça do artista não é um todo organizado, que coloca cada peça de seu quebra-cabeça no devido lugar para que ao final se tenha uma unidade, uma totalidade temática e formal. É possível que unidade e totalidade estejam mais ligadas à mediocridade. $\mathrm{O}$ que se passa então na cabeça de um escritor quando ele escreve? Várias são as possibilidades, as "regras" ou "leis" que sopram ao ouvido dos escritores segundo Blanchot:

L'une lui dit Tu n'écriras pas, tu resteras néant, tu garderas le silence, tu ignoreras les mots.

L'autre Ne connais que les mots.

- Écris pour ne rien dire.

- Écris pour dire quelque chose.

- Pas d'œuvre, mais l'expérience de toi-même, la connaissance de ce qui $\mathrm{t}^{\prime}$ est inconnu.

- Une œuvre! Une œuvre réelle, reconnue par les autres et important aux autres. 
- Efface le lecteur.

- Efface-toi devant le lecteur.

- Écris pour être vrai.

- Écris pour la vérité.

- Alors, sois mensonge, car écrire en vue de la vérité, c'est écrire ce qui n'est pas encore vrai et peut-être ne le sera jamais.

- N'importe, écris pour agir.

- Écris, toi qui as peur d'agir.

- Laisse en toi la liberté parler.

- Oh! en toi, ne laisse pas la liberté devenir mot.

Quelle loi ‘suivre?Quelle voix entendre? Mais, il doit les suivre toutes! Quelle confusion, alors; la clarté n'est-elle pas sa loi ${ }^{1}$

${ }^{1}$ BLANCHOT, 2003, p. 303.

Trad: Uma lei lhe diz Não escreverás, permanecerás o nada, guardarás silêncio, não conhecerás palavras.

Outra lei diz Não conheças nada além de palavras.

- Escreve para não dizer nada.

- Escreve para dizer algo.

- Nada de obras; antes a experiência de ti mesmo, o conhecimento do que te é desconhecido.

- Uma obra! Uma obra real, reconhecida pelas pessoas e importante para elas.

- Apaga o leitor.

- Apaga a ti mesmo diante do leitor.

- Escreve para ser verdadeiro.

- Escreve pelo amor da verdade.

- Então sê uma mentira, porque escrever com a verdade na mente é escrever o que ainda não é verdade e talvez jamais seja.

- Não importa, escreve para agir.

- Escreve - tu que tens medo de agir.

- Deixa a liberdade falar em ti.

- Oh! Não deixes a liberdade se tornar palavra em ti.

Que lei seguir?Que voz escutar?Mas ele deve segui-las a todas! Que confusão, então; a claridade não é sua lei? 
São muitas as leis. Qual ou quais seguir? O escritor deve ouvi-las a todas? Ouvir a todas não traz uma confusão imensa ao ato de escrever?

Nos últimos romances de Lobo Antunes, a profusão de vozes que falam - e sobretudo escrevem - dificulta discernir um rumo determinado da escrita. Se os enunciadores das vozes não se entendem sobre a propriedade de um mero par de luvas, que podem nem ser um par, como podem se entender a respeito da construção da escrita literária? Ouvimos muitas vozes nos romances de Lobo Antunes, os escritores ouvem muitas vozes, mas qual ou quais eles seguem?

Ouçamos as vozes do romance Que cavalos são aqueles que fazem sombra no mar? Todos falam, ninguém tem razão ou todos a têm. Além de todos os personagens mais notáveis escreverem, há um Lobo Antunes ficcional que se intromete na escrita a todo momento, um escritor que parece querer organizar os textos das vozes que escrevem. Tentemos perseguir as razões e desrazões dessas vozes, e como elas terminam construindo algo que as pessoas chamam romance. Considerar o "terminam" nos leva a outra questão fundamental neste texto: como termina o romance, se é que ele termina, o que é afinal seu acabamento? Outras indagações se impõem: que estrutura o sustenta? Qual o centro dessa estrutura? São esses desacertos, idas e vindas, desvios, esquecimentos, lacunas que compõem essa escritura instigante que nos propomos comentar neste ensaio.

$$
\text { *** }
$$

Antes da corrida, a enunciadora afirma que a mãe contou e contou o que lhe havia contado a mãe, e assim as brumas da memória baixam sobre a escritura a mostrar andares antigos em sua penumbra perpétua com pratas e loiças a seguirem 
quem conta, e a avó de quem conta a imaginar a tristeza do lugar: "-Como esta casa deve ser triste às três horas da tarde". 2

E a chuva do inverno, chuva que não é chuva, que não chove onde devia chover, "não lá fora e não chuva tão pouco", ${ }^{3}$ lava o que poderia ainda ser resquícios de memórias, mas que ao adentrarem a escritura são apenas sombras de um real improvável e impossível de se reativar, um real que tenta inutilmente revelarse no brilho efêmero de uma gota de saliva, no instante eterno de um dente que flutua à frente de uma boca, de um sorriso à frente do dente. Beatriz, enunciadora do primeiro texto, reconhece que seu mundo é uma desordem, que ela própria é uma desordem, ela que detestava o pai "por me desarrumar o passado". ${ }^{4}$ As vozes não provêm de corpos com bocas, os mortos se misturam aos vivos, $\mathrm{O}$ pai morto não pode responder à pergunta - Quem sou eu? -, que, afinal, nãoé perguntada. Os antepassados, os mortos não têm voz, o passado não sabe exprimir-se: "a minha bisavó e as senhoras nem uma palavra e no entanto falavam porque um brilho de saliva, um dente". ${ }^{5}$

A mãe, que deveria ser responsável pelo relato, a que contou e contou, não consegue formar frases, não se lembra das surpresas, nem da casa, nem da quinta, nem dos cavalos e toiros. Sua linguagem se assemelha a um estranho código de sinais manuais a percorrer o corpo: "sílabas de mão alastrando peito fora até o cobrir por inteiro", 6 ou então "sílabas de palma a alastrar peito fora até o cobrir por inteiro", 7 a dizer coisas que

${ }^{2}$ LOBO ANTUNES, 2009, p. 13.

${ }^{3}$ LOBO ANTUNES, 2009, p. 13.

${ }^{4}$ LOBO ANTUNES, 2009, p. 17.

${ }^{5}$ LOBO ANTUNES, 2009, p. 26.

${ }^{6}$ LOBO ANTUNES, 2009, p. 14.

${ }^{7}$ LOBO ANTUNES, 2009, p. 14. 
não significam nada, ou significam e ela, Beatriz, não consegue apreender, e portanto não poderá constituir um relato compreensível no livro. Mas ela, Beatriz, a filha, assume o relato e recusa a morte da mãe. Quando Ana, sua irmã, chora, ela afirma que ninguém morreu, "não foi a mãe, foi um bicho, não se morre cá em casa", ${ }^{8}$ e, ao recusar a morte da mãe, recusase a dar um termo ao relato, recusa vislumbrar uma conclusão, um lugar aonde chegar, assim não é possível a morte do touro, nem da mãe, nem da narrativa, que não se fecha.

Temos aí uma enunciadora que tenta recompor com dificuldade a memória, e chega-se à conclusão de que memória propriamente não há, o que predomina é o esquecimento e o caos:

com o leque e quem me garante que o reposteiro não o homem, que mal lhe fez o empregado senhora, cavalos e cavalos entre as roseiras, todas as casas são tristes às três da tarde derivado a essa noite interior que sucede ao meiodia e demora a passar com as pratas e as loiças no fundo de nós e a memória de um par de luvas no chão sem que recordemos a quem pertenciam, que estranho viver, como se faz, começa-se por onde, em que capítulo... ${ }^{9}$

O trecho evoca bem o processo de escrita do romance, que parece não ter um rumo certo, que não sabe separar memória de invenção, que não consegue se apoiar em fatos consistentes que confiram solidez ao relato e tornem a trama convincente e terminante. A inconsistência dos propósitos de quem escreve ilumina o fragmento: "luvas no chão sem que recordemos a quem pertenciam", e essa luz de que me aproprio conduz a outra apropriação: o texto "Restitutions", de Derrida, a propósito de uns certos sapatos - e também luvas! - de Van

${ }^{8}$ LOBO ANTUNES, 2009, p. 24.

${ }^{9}$ LOBO ANTUNES, 2009, p. 16. 
Gogh, ou melhor, de certos sapatos e luvas pintados por Van Gogh e que são pretensamente restituídos a seus legítimos donos por Martin Heidegger e Meyer Schapiro, resultando daí uma bela discussão a respeito da obra de arte na perspectiva da desconstrução.

Em A origem da obra de arte, Heidegger faz referência a "uma conhecida pintura de Van Gogh, que pintou várias vezes calçado deste gênero", ${ }^{10}$ sem definir exatamente qual, mas certamente um quadro que apresenta sapatos pintados. Em seguida, diz que eles pertencem a uma camponesa, cria uma narrativa com a personagem e seus sapatos e utiliza a obra como uma figuração para sustentar seu discurso a respeito do embate entre "mundo" e "terra", noção importante para se entender o que para Heidegger é a origem da obra de arte. Algumas décadas depois, o historiador de arte Meyer Schapiro escreve um texto desautorizando a "restituição" dos sapatos à camponesa por Heidegger, e faz sua própria restituição: os sapatos são de um homem, e um homem urbano, e mais certamente do próprio Van Gogh.

Derrida então discute a questão da não-correspondência entre o que a restituição pretende fazer e o que ela efetivamente faz. Essa não-correspondência deve-se ao fato de que não há restituição em nenhum dos dois discursos, mas uma apropriação. Schapiro insiste em suas ideias e não percebe as ideias de Heidegger, inclusive uma fundamental: a de que para este realmente não importa de quem sejam os sapatos, a de que ele se apropria da figura da camponesa como alegoria para sua discussão sobre "mundo" e "terra". E a utilização da imagem da camponesa e seus sapatos está relacionada à intenção de Heidegger exatamente de negar a representação, de sua tentativa de ver a arte como um fenômeno imanente, e não como representação da realidade. Isso Schapiro parece não

${ }^{10}$ HEIDEGGER, 2008, p. 24 
conseguir ver, e chega a atribuir a atitude de Heidegger, segundo Duque-Estrada, ao "sintoma de uma patologia nacional-socialista", ${ }^{11}$ uma referência evidente à adesão de Heidegger ao partido Nazista na Alemanha em 1933. Segundo Derrida, reportado por Duque-Estrada, "nem Heidegger nem Schapiro suportam, cada um a seu modo, o caráter abandonado, largado, separado, desgarrado, dos sapatos"12 e atribui aos sapatos um dom alucinógeno: tudo o que dizem Heidegger e Schapiro a respeito deles faz parte de uma "dramaturgie délirante", uma alucinação: "Ces souliers sont allucinogènes". ${ }^{13}$ Como um par de luvas, "comme um paire de gants", 14 igualmente alucinógenas. Van Gogh pintou luvas em 1889, em Arles, as quais Schapiro insiste em considerar objetos pessoais (restituindo-as ao dono), procedimento que estende a outras naturezas mortas: tudo na arte tem que ter um dono, as atribuições e restituições têm que ser feitas para a tranquilidade do apreciador de arte.

Volvendo a Beatriz, ela registra em seu depoimento a presença de um par de luvas, igualmente abandonados, sem dono. A voz de Beatriz parece ocupar uma posição, se não podemos dizer privilegiada, ao menos notável: ela escreve "antes da corrida" e "depois da corrida", à guisa, respectivamente, de "prólogo" e "epílogo", o que pode sugerir que também escuta as outras vozes que compõem o relato, ou até que ela apresenta e fecha o grande relato, sob o olhar atento-ou escuta atenta-de um certo António Lobo Antunes. Nesse sentido, pode-se ler o fragmento que menciona as luvas abandonadas como uma

${ }^{11}$ DUQUE-ESTRADA, 2010, p. 338.

${ }^{12}$ DUQUE-ESTRADA, 2010, p. 339.

${ }^{13}$ DERRIDA, 2010, p. 312.

14 DERRIDA, 2010, p. 307. 
advertência: a narrativa não tem a quem ou a quê ser restituída, seja a um proprietário, a um centro, a uma estrutura, a um acabamento, a uma conclusão.

A arte não é feita para retornar a lugar nenhum, a ser restituída a coisa alguma. A arte existe para existir, para estar lá, a arte é. A obra de arte, o texto literário não encontra seu valor na ligação com o mundo, ou quando contém uma ideologia, quando propicia uma reflexão existencial, quando representa. Preservar a condição de inútil é fundamental para a existência da obra de arte. É o que os grandes artistas e escritores parecem querer nos dizer a todo momento e os críticos parecem não aceitar, exatamente porque a arte "est originairement ce détachement qui perd pied". ${ }^{15}$ Como perder o pé, como perder o rumo e continuar falando de um objeto que não segue um caminho preestabelecido, que não anda por uma estrada pavimentada, um objeto que resiste à sistematização, à organização, à classificação?

E as luvas estão lá no chão, sem proprietário, sem nenhum nome associado a elas, é o que fica na memória, nada mais, não a primeira noite de sexo aos dezoito anos dentro do carro, não as nódoas da relação nas roupas íntimas, viradas e reviradas e cheiradas pela mãe, a perguntar insistentemente: "-O que é isto?". Não a gravidez indesejada, não o casamento por obrigação, não a vida conjugal insossa, não a separação anódina, não o filho que pouco aparece - "(do meu filho não falo)"16 -, pouco resta na memória, sombras opacas do pai na quinta a cavalo, ela em sua garupa, os nomes dos ex-maridos lembrados a custo, o cão atropelado que foi sacrificado, a primeira experiência sexual, a gravidez, os casamentos e as

${ }^{15}$ DERRIDA, 2010, p. 391. Trad.: "é originariamente essa separação que perde o rumo".

${ }^{16}$ LOBO ANTUNES, 2009, p. 24. 
separações. E, presidindo a todo o esquecimento, a figuração dos cavalos que fazem sombra no mar, repetida insistentemente durante todo o romance, em todas as vozes que se manifestam.

Fazer sombra no mar parece ser um símbolo de poder, ainda que um poder claudicante, que não se afirma. Beatriz, quando ia à praia, pensava nos cavalos entre as roseiras e "imaginava-os na linha das ondas fazendo sombra no mar". ${ }^{17}$ João, o homossexual "que tinha a doença a doença a doença", 18 seria sempre considerado o maricas, o que envergonhava a família, o que "não montava os cavalos que faziam sombra no mar" ${ }^{19}$ Para João, o pai é um enorme cavalo, a fazer "imensa sombra no mar", 20 isto é, a ter a obediência de todos, empregados e touros, a ter as filhas dos empregados para seu desfrute sexual sem contestação. Quando João se compara aos cavalos, que se angustiam na prisão da manjedoura, Beatriz o adverte de que ele não faz sombra no mar, e ele se conscientiza de sua condição inferior: "não faço sombra no mar, não faço sombra no parque, não faço sombra no corredor...". ${ }^{21} \mathrm{O}$ pai, entretanto, minimiza o poder de sua sombra, que não chega ao mar, possivelmente a penas faz sombra em seus domínios limitados, e preconiza que talvez um dia a própria Beatriz, sua filha mais velha, faça sombra no mar. ${ }^{22}$ E reafirma frequentemente a tolice que é a ideia da Beatriz de os cavalos fazerem sombra no mar. Para Francisco, colocar os cavalos no mar significa vender a casa em Lisboa e a quinta e embolsar

${ }^{17}$ LOBO ANTUNES, 2009, p. 16.

${ }^{18}$ LOBO ANTUNES, 2009, p. 75.

${ }^{19}$ LOBO ANTUNES, 2009, p. 75.

${ }^{20}$ LOBO ANTUNES, 2009, p. 77.

${ }^{21}$ LOBO ANTUNES, 2009, p. 80.

${ }^{22}$ LOBO ANTUNES, 2009, p. 89. 
tudo para si, deixando os irmãos à deriva. Pode-se dizer que esses cavalos do título fazem uma grande sombra na escritura, nesse mar de palavras a que nenhum dos muitos escritores, $\mathrm{e}$ todos num só, consegue controlar e imprimir uma direção.

A sombra dos cavalos pisa o passado da enunciadora e de sua mãe e de toda sua família. Ela sabe que não consegue concatenar o que escreve, e sabe que há um escritor por ali que parece conduzir sua escrita, que não lhe dá liberdade, que a força a omitir fatos: "não esclareço isso bem porque as palavras avançam depressa e o papel não chega, eis o António Lobo Antunes a saltar frases não logrando acompanhar-me e a afogar num tanque os gatinhos do que sinto para se desembaraçar de mim". ${ }^{23}$ Mais adiante, a irmã Ana dirige-se ao escritor afirmando que este livro é o seu testamento, seu último livro, e sugere que ele seja sincero, que seja direto: "não embelezes, não inventes". ${ }^{24}$ Assim, o Lobo Antunes de palavras também não tem a direção segura do empreendimento, ele que também é admoestado por seus personagens, que inúmeras vezes fogem dos desígnios de escritor. Se este livro é o testamento dele, pode-se apostar numa herança de narrativas de direção incerta.

Todos sabem, enfim, que isto é um livro, e as memórias e não-memórias, impossíveis de se dissociarem e de se identificarem, vão-se superpondo numa enumeração caótica de frases, cenas e figuras. Num determinado momento surgem os gatos, "há alturas no escuro em que só os gatos se acendem, que fazem eles no livro", ${ }^{25}$ por que estão aí os gatos? Quem controla o que vai no livro? De que região da memória da infância saem esses gatos opacos, plenos de ambiguidade blanchotiana contra a transparência dos gatos sartrianos? E assim vai o texto e seus

${ }^{23}$ LOBO ANTUNES, 2009, p. 22.

${ }^{24}$ LOBO ANTUNES, 2009, p. 123.

${ }^{25}$ LOBO ANTUNES, 2009, p. 24. 
enunciadores, a "encher a página de sumaúma e silêncio", ${ }^{26} \mathrm{a}$ fronde enorme a fazer sombra à escritura que não diz nada. Afinal, para que tentar ordenar um mundo escritural se alguém virá para desordená-lo e mantê-lo sempre assim?

É curioso que tal desordem apresente-como é praxe nos romances de Lobo Antunes - uma moldura simétrica, que parece organizar o texto, conferir-lhe uma consistência metódica que se esvai pelas frestas dos caixilhos, sem lograr reter a integridade da narrativa, que afinal se dispersa além dos limites paratextuais previamente estabelecidos. A suposta ordenação no caso de Que cavalos são aqueles que fazem sombra no mar? compreende as fases de uma tourada espanhola - coerente com a condição de criador de touros do personagem em torno do qual falam os filhos -, e sugere evidentemente uma sequência cronológica, e mais do que uma cronologia, uma estrutura narrativa. Temos então inicialmente um capítulo intitulado "antes da corrida", uma espécie de prólogo cuja estrutura parece antecipar o caos que a moldura tenta desmentir. Em seguida vêm cinco partes que compõem o miolo do livro: "tércio de capote", "tércio de varas", "tércio de bandarilhas", "a faena" e "a sorte suprema", cada qual contendo quatro capítulos, de tamanhos similares, e ao final há um capítulo à guisa de epílogo, chamado "depois da corrida". Os títulos das partes referem-se a momentos da corrida de touros espanhola, ou tourada. Assim, toda essa "armadura" pressupõe um jogo, uma corrida, uma sequência, com início, meio e fim bem estabelecidos, até a sorte suprema - a morte do touro. Os dois primeiros tércios têm como função estressar e cansar o touro: no tércio de capote, o volteio

${ }^{26}$ LOBO ANTUNES, 2009, p. 24. 
da capa atiça o touro; no tércio de varas os picadores minam a resistência do animal ferindo-o com lanças de ponta em forma de $T$, para que a crueldade da estocada não seja fatal, por enquanto. O tércio de bandarilhas tem como objetivo deixar o touro ainda mais furioso, e mais enfraquecido, para que o toureiro o mate para sua glória. Nessa parte da corrida os banderilleros entram em cena, cravando três pares de estacas coloridas, com ponta de arpão, no pescoço do animal. Na faena, o toureiro com sua capinha vai se exibir à plateia, driblando o animal de perto e correndo um certo risco. Em seguida ele recebe uma longa espada com a qual liquida a fatura: fazendo volteios com a capa rente ao chão, ele deixa o touro de cabeça baixa e patas dianteiras juntas, posição ideal para cravar a espada na área acima do pescoço, visando a aorta do animal. Em seguida vem a "sorte suprema", eufemismo para a cruel eliminação do touro, que não raro morre afogado em seu próprio sangue, que lhe jorra aos borbotões da boca e do nariz. Se o toureador atuou de forma gloriosa, sua prenda suprema são as duas orelhas e o rabo do animal sacrificado, que são arrancados na hora e dados como troféu ao protagonista da corrida.

Não é difícil relacionar essa estrutura à construção da narrativa tradicional, que compreende o epílogo, que anuncia o relato e cria a expectativa em torno do que se vai narrar; uma situação inicial aparentemente calma; em seguida o elemento perturbador; o desencadeamento do conflito; o clímax e o repouso, com direito a epílogo. Entretanto, não é nada disso o que acontece no romance de Lobo Antunes. É evidente que a arquitetura externa escolhida pelo escritor não cumpre uma finalidade diegética - a divisão em partes não corresponde ao acúmulo de tensões e consequentes distensões do texto narrativo previsível. Tudo indica que Lobo Antunes estabelece seus caixilhos para evitar que passe o resto da vida escrevendo o mesmo romance. 
A estrutura anuncia uma forma acabada, com seu centro bem definido (a atuação do herói; no caso, o toureiro) e todas as suas ações convergentes para o desfecho, o desenlace, a conclusão. Aqui, entretanto, o conteúdo desmente a forma.

No interior dessa armação temos os delírios desmemoriados de vozes que se alternam: o criador de touros, seus quatro filhos (Beatriz, Francisco, João e Rita) e uma meiaparente bastarda, Mercília. A família enfrenta condições adversas nas relações entre as pessoas e sua saúde: doenças, uso de drogas, homossexualismo, instabilidade matrimonial, jogos de azar, adultério, sexismo, praticamente os mesmos elementos presentes nos demais livros de Lobo Antunes. E como na maioria dos romances anteriores, há a mesma pluralidade de vozes, que ao final é uma só, a mesma escritura angustiada, que parece não saber para onde vai, e que a todo momento no decorrer dos relatos denuncia sua condição de desmemoriada, de desorganizada, de desordenada. Mas tudo isso presidido por uma linguagem que permanece fascinante, intrigante, empolgante, típica do escritor.

Ao final do prólogo, Beatriz parece se conciliar com o pai, visto agora como amigo, e a sombra de pai e filha se engrandecem, se magnificam a ponto de impedi-los de ver a cabeça de um touro sobre um corpo que não fala a ninguém, um corpo que um último "- Tu" (p. 28) ${ }^{27}$ permite identificar como sendo o da mãe, um corpo "que não se dirige a ninguém, no interior de uma caixa amolgada" (p. 26). ${ }^{28} \mathrm{~A}$ imagem de Beatriz sendo levada pelo pai a lhe cingir a cintura se sobrepõe a todas as outras, da casa, do quarto, de Lisboa, da quinta, da mãe morta, o que faz supor algum tipo de acordo, de conciliação que não se concretiza na escritura.

\footnotetext{
${ }^{27}$ LOBO ANTUNES, 2009, p. 28.

${ }^{28}$ LOBO ANTUNES, 2009, p. 66.
} 
Como em geral ocorre nos romances de Lobo Antunes, todos estão aqui a escrever um livro. O primeiro depoimento depois do prólogo de Beatriz é de Francisco, seu irmão, que trapaceia com o notário para ficar com todos os bens da família para si, e ao se apor o último dos carimbos à fraude burocrática, ele se declara "feliz, ia escrever feliz e escrevo feliz, a contemplação feliz da obra acabada" ${ }^{29}$ A obra acabada, sim, a obra dos homens, das compras e vendas, dos ardis que se apropriam e conferem donos às coisas por força da lei, ainda que burlada. A contemplação da obra que tem um fim e dá prazer. A trapaça nos cartórios tem um termo, uma finalidade, um destino, a trapaça na literatura não tem rumo. O mesmo Francisco se apavora com a possibilidade do infinito, o horror da morte que não mata: "é isso que me assusta na morte, a hipótese do não fim do que vivemos", como a impossibilidade da morte na escritura: "tudo idêntico de maneira diversa, a intensidade das emoções, as lágrimas e o riso intactos" ${ }^{30} \mathrm{Em}$ outros relatos, Francisco demonstra saber que escreve o livro, ou que ajuda a escrevê-lo, e que outras pessoas também escrevem o mesmo livro, e parece inclusive saber o que as outras pessoas dizem. Quando pronuncia, por exemplo, a frase "como esta casa deve ser triste às três horas da", ${ }^{31}$ ele se interrompe, afirma que não é ele quem diz isso mas outra pessoa, talvez o irmão João, talvez o maioral, ou capataz da fazenda. Quem contudo pronuncia a frase pela primeira vez, a personagem a quem é atribuído o dizer é a avó deles. Já na seção intitulada "antes da corrida", na primeira página do romance, Beatriz cita a frase como sendo da avó aos onze anos, segundo o relato da mãe. O impulso da escritura faz com que

${ }^{29}$ LOBO ANTUNES, 2009, p. 37.

${ }^{30}$ LOBO ANTUNES, 2009, p. 42.

${ }^{31}$ LOBO ANTUNES, 2009, p. 102. 
Francisco declare sentimentos inconfessáveis, como o desejo de que Mercília fosse sua mãe, a mesma Mercília que ele expulsou da quinta, a filha bastarda do bisavô Marques; ele então ameaça destruir a página onde se lê o que não deveria ter sido escrito. ${ }^{32}$ Em meio à escrita, a caneta de Francisco resolve enguiçar, ele pergunta como acabar o parágrafo, como terminar o capítulo. ${ }^{33}$

Francisco dá cinco depoimentos, sempre o primeiro de cada uma das partes, e sempre fazendo variações sobre os mesmos temas: os desmandos do pai, sua preocupação com o que lhe sobra da herança, o golpe contra os irmãos, a mulher que o visita às quartas-feiras, as críticas aos irmãos e irmãs, a expulsão de Mercília, uma ou outra revelação que não surpreende, como o fato de a mãe ter tido um amante, a consciência de que escreve um livro e a exasperação por estar escrevendo-o, a morte da mãe e o final do livro com hora marcada. No último depoimento ele afirma o óbvio; que esse será o último, porque já deram as seis horas: "chegando ao final deste capítulo evaporo-me". ${ }^{34}$ Não há progressão, não há evolução nos relatos.

Ana, também irmã, que rouba o dinheiro da filha bastarda do avô, feita empregada da quinta, Mercília, também sabe que está a escrever e mostra-se envergonhada de ter que escrever o que escreve: "(estou a demorar imenso a contar isto porque tenho vergonha do que vou escrever) $)^{\prime \prime} .{ }^{35} \mathrm{E}$ sabe ainda que suas palavras estão sendo escritas em um livro. Ao se referir à irmã Rita, que morreu de câncer, recusa-se a recordar a doença e morte da irmã, e deixa ao encargo de outra pessoa o relato de suas penas:

\footnotetext{
${ }^{32}$ LOBO ANTUNES, 2009, p. 109.

${ }^{33}$ LOBO ANTUNES, 2009, p. 116.

${ }^{34}$ LOBO ANTUNES, 2009, p. 305.

${ }^{35}$ LOBO ANTUNES, 2009, p. 51.
} 
"alguém, não eu que me custa recordá-la, falará disso no livro". ${ }^{36}$ Em outro momento, Ana duvida de que ela mesma esteja escrevendo, pergunta-se quem estará escrevendo por ela, e chama o livro um "romance de espectros". ${ }^{37}$

Ana também tem uma participação regular na escritura, ocupando sempre o segundo depoimento de cada parte, no total de cinco enunciações. Sabe-se que julga-se feia, que rouba Mercília para comprar droga, que parece ser a mais inteligente dos irmãos, e pouca coisa mais.

O terceiro a dar regularmente seu depoimento é João, que ocupa o terceiro relato das três primeiras partes. Também ele faz voltas sobre os mesmos assuntos, sem acrescentar muito ao relato: sua condição de homossexual apreciador de rapazinhos, de portador de AIDS, de preferido da mãe. Em meio ao seu depoimento, enquanto relata sua vida miserável, aparece a pergunta parentética estarrecedora: "(acabarei este livro?)". ${ }^{38} \mathrm{E}$ logo adiante: "(como me aborrece o que escrevo)". Quem pergunta? Quem demonstra seu aborrecimento? Embora o enunciador neste momento seja João, nada garante a autoria da pergunta ou a do comentário. É alguém que escreve. João ou outro. É curioso que em meio a uma lista de tarefas, ou de acontecimentos, aparece a expressão "impedir a minha mãe de falecer" ${ }^{\prime \prime}{ }^{39} \mathrm{e}$ imediatamente uma voz também não identificada se levanta: "- Não autorizo". ${ }^{40}$ João fantasia ainda um almoço entre o autor do livro e as personagens inventadas por ele: "Apetece-lhe almoçar com a gentinha que inventou?" (p. 138) ${ }^{41}$

\footnotetext{
${ }^{36}$ LOBO ANTUNES, 2009, p. 56.

${ }^{37}$ LOBO ANTUNES, 2009, p. 130.

${ }^{38}$ LOBO ANTUNES, 2009, p. 77.

${ }^{39}$ LOBO ANTUNES, 2009, p. 77.

${ }^{40}$ LOBO ANTUNES, 2009, p. 77.

${ }^{41}$ LOBO ANTUNES, 2009, p. 138.
} 
Mercília, ao final de seu depoimento, o ultimo do "tércio de varas", refere-se ao desânimo do escritor em relação a sua história e suas personagens: "e se o António Lobo Antunes batesse isso no computador carregava em teclas ao acaso, não importam quais, até o fim da página, letras, números, vírgulas, traços, cruzes". ${ }^{42}$ Se dependesse de sua vontade, o escritor desejaria que todos morressem afogados nas cheias do Tejo. As pessoas precisam morrer, têm direito à morte, mas a escritura lhes nega tal direito, os seres morrem mas em seguida aí estão eles "na conversa". ${ }^{43}$

Há vozes que se intrometem na fala do João, que tanto podem ser intervenções do próprio João, quanto de sua irmã Beatriz, supondo-se que ela seja a enunciadora principal, quanto pode ser o escritor, um Lobo Antunes ficcional, que se anuncia aqui e ali. Essas vozes, geralmente parentéticas, comentam a enunciação, replicam, duvidam, corrigem os ditos, aconselham o narrador, e se referem constantemente à escrita, "era você quem devia escrever isso", ${ }^{44}$ e o que compõe o livro participa das intimidades da família. Há momentos em que se tem a nítida impressão de que os personagens fazem depoimentos que são transcritos pelo autor, o António Lobo Antunes do livro, como num momento em que João demonstra uma ternura inusual com a mãe, e um ser chamado Lobo Antunes pergunta "- Escrevo assim?", e ele, João, responde: "- Escreva." 45

Assim, os seres de papel, seres que só existem como nomes, como linguagem, o que inclui o António Lobo Antunes presente neste relato (que aqui escreve seu último livro, embora

${ }^{42}$ LOBO ANTUNES, 2009, p. 166.

${ }^{43}$ LOBO ANTUNES, 2009, p. 136.

${ }^{44}$ LOBO ANTUNES, 2009, p. 137.

${ }^{45}$ LOBO ANTUNES, 2009, p. 140. 
já tenham aparecido vários depois deste da autoria do outro Lobo Antunes), vivem e revivem, morrem e desaparecem, e afinal não são nada, "é um livro e eu uma criatura do livro, não uma pessoa a sério, tranquiliza-te que apenas vives se o compram" ${ }^{46}$ Há controvérsias se isto é um livro ou não, Beatriz impacienta-se e manda o João calar-se, Mercília diz que só fala sobre seu pai, o bisavô Marques, se certificar-se de que isso não é um livro, afinal certifica-se mas não se sabe se ela fala.

E João se declara aborrecido com essa escrita, perturbado com a possibilidade de estar desvendando segredos que não podem ser revelados, em sua tentativa de fazer as coisas terem nexo, de ver se consegue fechar alguma coisa no relato, de posse de "chaves que nem o passado abriam". ${ }^{47}$

A voz do pai, que aparece no quarto depoimento da primeira parte, também sabe que um livro está sendo escrito, e afirma que está no mês de novembro, e não "de março como pretende o que faz o livro". ${ }^{48} \mathrm{O}$ que faz o livro, na leitura do proprietário da quinta, fala mentiras e fala verdades, mas iludese ao pensar que as palavras o salvam, quando não valem nada, são meros sinais que se exibem em um dicionário para uso de quem escreve. A família do escritor, seus parentes, assemelhamse muito à família dos que fazem parte do livro, afinal quem é real, quem é ficcional? A morte, ou não-morte, parece ser um indicativo de que eles nada mais são do que personagens de um livro. O pai refere-se ao próprio funeral, lembra que a filha Ana estava lá, e que fala hoje da morte do pai, entretanto ele está no livro, continua falando, confuso sobre a possibilidade de ter morrido e permanecer ali: "e no entanto continuo, não é o que faz o livro que me continua, sou eu ou qualquer nervo

\footnotetext{
${ }^{46}$ LOBO ANTUNES, 2009, p. 142.

${ }^{47}$ LOBO ANTUNES, 2009, p. 145.

${ }^{48}$ LOBO ANTUNES, 2009, p. 83.
} 
moribundo a persistir, não dou fé da boca ou da língua e não estou certo que fale" ${ }^{\prime 4}$

Ninguém está certo do que fala, e nem mesmo de que está a falar. A escritura é tagarela, mas não diz nada, dirige-se ao silêncio.

Depois da corrida, que parece situar-se um mês depois da morte da mãe, Beatriz tenta atar os fios do relato, sentada nos degraus do estacionamento em frente ao mar, possivelmente o mesmo cenário de antes da corrida. Por duas vezes o depoimento é corrigido por ela mesma: "Não ficou bem, recomeça", 50 e em sua correção, não vê mais as luzes de barcos, nem ouve as ondas. Vê cenas interiores e ouve vozes muito antigas, "- Tudo sujo tudo sujo", 51 não apenas a voz suja de dona Mimi - por mais que a enunciadora a queira nítida -, mas tudo o que se imagina ser um passado que as páginas de um livro supostamente resgatam. E nos pensamentos de Beatriz intrometem-se as reflexões de sua mãe, Maria José, sobre a morte, sobre sua recusa de morrer, o pavor de se ver no caixão, de ser esquecida e desaparecer.

Nas últimas linhas Beatriz declara-se esquecida dos tormentos da mãe, e recolhe-se novamente sozinha a ouvir "as vozes que me acompanham desde sempre" ${ }^{52} \mathrm{O}$ final convida a uma reflexão sobre o final. Beatriz afirma: "e mal as vozes se calarem levanto-me e regresso a casa. Quer dizer não sei se tenho casa mas é a casa que regresso". ${ }^{53}$ Por tudo o que se ouviu

${ }^{49}$ LOBO ANTUNES, 2009, p. 89.
${ }^{50}$ LOBO ANTUNES, 2009, p. 371.
${ }^{51}$ LOBO ANTUNES, 2009, p. 371.
${ }^{52}$ LOBO ANTUNES, 2009, p. 375.
${ }^{53}$ LOBO ANTUNES, 2009 , p. 375. 
durante o romance, as vozes não vão se calar, e como as vozes não se calarão, Beatriz não voltará à improvável casa, à casa que ela nem sabe se existe. Assim acaba o romance, sem acabamento. O que deveria ser um epílogo, um desfecho, uma conclusão, mantém o relato no ar, sem se saber aonde vai.

$\mathrm{Na}$ contramão dessa concepção de acabamento - ou inacabamento-,Emmanuel Levinas afirma, em tom de queixa, que toda obra de arte é acabada. Não acabada no sentido que a estética da Arte pela Arte dá ao termo acabamento, e nem na concepção de algo interrompido, mas acabada no sentido de desvincular-se, de tornar-se livre da compreensão, do conhecimento:

On sous-estime l'achèvement, sceau indélébile de la production artistique, par lequel l'œuvre demeure essentiellement dégagée; l'instant suprême où le dernier coup de pinceau est donné, où il n'y a plus um mot à ajouter, ni um mot à retrancher au texte et par lequel toute œuvre est classique..$^{54}$

Nesse sentido, e apenas nele, pode-se dizer que a literatura de Lobo Antunes é acabada: nesse ponto, a obra se recusa a receber qualquer palavra a mais, embora as vozes continuem a falar, e nesse momento o artista se detém.

Nas últimas linhas do ensaio "La littérature et le droit à la mort", Blanchot insiste em diferenciar a linguagem cotidiana da linguagem literária. No discurso corrente, a força de negação das palavras conduz ao sentido e à compreensão apaziguadoras, porque negação e morte são potências do mundo real. No

\footnotetext{
${ }^{54}$ LEVINAS, 1994, p. 109. Trad.: Subestima-se o acabamento, selo indelével da produção artística, pelo qual a obra se mantém essencialmente livre; o instante supremo em que a derradeira pincelada é dada, em que não há mais uma palavra a acrescentar, nem uma palavra a eliminar no texto e pelo qual toda obra é clássica.
} 
momento em que o signo literário falha ao representar o que havia morrido, emerge o nada da morte, e a verdade não mais se revela, isto é, o escritor não pode agir "verdadeiramente". No movimento ligado aos afazeres do mundo, a morte apresenta um poder civilizatório que torna possível a existência dos seres, por mais que ela conduza o homem à infelicidade; assim, a morte está para o homem cotidiano como o sentido está para a palavra útil. Daí a insistência de Blanchot na afirmação "a morte resulta no ser": seja loucura, infelicidade ou dilaceramento, só ela possibilita ao homem a compreensão, a apreensão dos sentidos das coisas.

Do outro lado da morte e da compreensão está a literatura. Experimentá-la é cair além da possibilidade da morte, além da possibilidade de compreender, é chegar ao domínio onde " 1 'issue devient la disparition de toute issue". ${ }^{55}$ As luvas não encontrarão mãos que se encaixem nelas com perfeição, jamais serão restituídas ao verdadeiro dono para felicidade do desenlace. Não há, portanto, saída para o relato, por mais que Beatriz acene com a promessa de voltar para casa. Aliás, voltar para casa parece ser a promessa da literatura, mas uma promessa que não pode jamais ser cumprida, como se o voltar para casa estivesse sempre em uma linha no horizonte, tênue, leve, indefinida, como se o texto fosse sempre nessa direção sem direção, e que essa linha sempre se afastasse, delicadamente, docemente. E quanto mais ela se afasta, e quanto mais nos aproximamos, mais somos seduzidos e mais nos apaixonamos. Isso nos faz, a nós e à literatura, continuar andando, e caminhando, e seguindo. Por isso a arte vale a vida.

55 BLANCHOT, 2003, p. 331. Trad.: "a conclusão se torna o desaparecimento de qualquer conclusão". 


\section{Referências}

ANTUNES, António Lobo. Que cavalos são aqueles que fazem sombra no mar? Lisboa: Dom Quixote, 2009.

BLANCHOT, Maurice. La litérature et le droit à la mort. In: La part du feu. Paris: Gallimard, 2003.

DERRIDA, Jacques. Restitutions. In: La vérité en peinture. Paris: Champs-Flammarion, 2010.

DUQUE-ESTRADA, Paulo César. Derrida: o pensamento da desconstrução diante da obra de arte. In: HADDOCK-LOBO, Rafael (Org.). Os filósofos e a arte. Rio de Janeiro: Rocco, 2010.

HEIDEGGER, Martin. A origem da obra de arte. Lisboa: Edições 70, 2008.

LEVINAS, Emmanuel. La réalité et son ombre. In: Les imprévus de l’histoire. Paris: Fata Morgana, 1994.

\section{Resumo}

Este texto se propõe comentar os desacertos, idas e vindas, desvios, esquecimentos, lacunas que compõem a escritura instigante de Lobo Antunes no romance Que cavalos são aqueles que fazem sombra no mar?, bem como indagar sobre a estrutura do relato, seu (in-) acabamento, sua ausência de saídas, de seus movimentos e deslocamentos do outro lado da morte e da compreensão.

\section{Résumé}

Cet article a le but d'examiner des erreurs, des tours et des détours, des déviations, des omissions et des lacunes qui sont à l'intérieur de l'écriture instigatrice de Lobo Antunes dans le roman Que cavalos são aqueles que fazem sombra no mar?, et aussi mettre en relief la structure de la narration, l'(in-) achèvement, le manque de sorties, les mouvements et les déplacements de l'autre côté de la mort et de la compréhension. 